\title{
Bipolar disorder first episode and suicidal behavior: are there differences according to type of suicide attempt?
}

\author{
A polaridade do primeiro episódio no transtorno bipolar \\ é um preditor para tentativa de suicidio (violenta e \\ não violenta) futura?
}

\section{Fernando Silva Neves, ${ }^{1}$ Leandro Fernandes Malloy-Diniz, ${ }^{2}$ Izabela Guimarães Barbosa, ${ }^{3}$ Paulo Marcos Brasil, ${ }^{3}$ Humberto Corrêa ${ }^{1}$}

\begin{abstract}
Objective: The objective of this study was to test the hypothesis that the polarity of the first mood episode may be a marker for suicidal behavior, particularly the violent subtype. Method: One hundred and sixty-eight patients diagnosed with bipolar disorder (DSM-IV) were grouped according to type of first episode: depression or manic/hypomanic. Groups were compared for demographic and clinical variables. We performed logistic regression in order to test the association between first episode polarity and suicidal behavior. Results: We found that depressed patients have a lifetime history of more suicide attempts. However, univariate analysis of number of suicide attempts showed that the best model fits the bipolar I/ subtype (mean square $=15.022 ; p=0.010$ ) and lifetime history of psychotic episodes (mean square $=17.359 ; p=0.021$ ). Subgrouping the suicide attempts by subtype (violent or non-violent) revealed that manic/hypomanic patients had a greater tendency toward attempting violent suicide (21.2 vs. 14.7\%, $X^{2}=7.028, p=0.03$ ). Multiple logistic regression analysis confirmed this result. Conclusion: Depressed patients had more suicide attempts over time, which could be explained by the higher prevalence of bipolar II subtype in this group, whereas manic/hypomanic patients had a lifelong history of more frequent violent suicide attempts, not explained by any of the variables studied. Our results support the evidence that non-violent suicide attempters and violent suicide attempters tend to belong to different phenotypic groups.
\end{abstract}

Descriptors: Bipolar disorder; Suicide attempted; Psychotic disorders; Dangerous behavior; Diagnosis

\section{Resumo}

Objetivo: 0 estudo pretende avaliar se a polaridade do primeiro episódio de humor prediz o comportamento suicida no transtorno bipolar, especialmente a tentativa de suicídio violenta. Método: Foram avaliados 168 pacientes com diagnóstico de transtorno bipolar (DSM-IV) subdivididos em dois grupos de acordo com a polaridade do primeiro episódio de oscilação do humor: se primeiro episódio foi depressão $(P D)$ ou se primeiro episódio foi de mania (PM). Comparamos as variáveis clínicas e demográficas dos dois grupos através do teste do qui quadrado e analisamos os resultados utilizando a regressão logística e análise univariada. Resultados: Os pacientes definidos como PD apresentaram maior número de tentativas de suicídio ao longo da vida. Entretanto, após analisar os resultados através do método estatístico univariado, verificou-se que as únicas variáveis associadas com histórico de múltiplas tentativas de suicídio foram o diagnóstico de transtorno bipolar do tipo // (mean square $=15,022 ; p=0,010$ ) e a história de sintomas psicóticos (mean square = 17,359; $p=0,021$ ). Ao avaliar a questão sob a perspectiva do tipo de tentativa de suicídio (se violenta ou não violenta), encontramos que os pacientes PM apresentavam maior probabilidade de cometer tentativas de suicídio violentas ao longo da vida (21,2\% vs. 14,7\%, $\left.X^{2}=7,028, p=0,03\right)$. A análise estatística por regressão logística múltipla confirmou os resultados encontrados. Conclusão: Apenas 0 diagnóstico de transtorno bipolar tipo /l e a existência de sintomas psicóticos são fatores associados com histórico de múltiplas tentativas de suicídio. A polaridade do primeiro episódio não está associada com o número de tentativas de suicídio em geral, entretanto existe associação entre tentativa de suicídio violenta e primeiro episódio de polaridade maníaca. Os resultados reforçam a evidência de que a tentativa de suicídio violenta é diferente da tentativa de suicídio não violenta, do ponto de vista fenotípico.

Descritores: Transtorno bipolar; Tentativa de suicídio; Transtornos psicóticos; Comportamento perigoso; Diagnóstico

\footnotetext{
1 Department of Mental Health, Medical School, Universidade Federal de Minas Gerais (UFMG), Belo Horizonte (MG), Brazil

2 Department of Psychology, Universidade Federal de Minas Gerais (UFMG), Belo Horizonte (MG), Brazil

3 Graduate Program in Neurosciences, Universidade Federal de Minas Gerais (UFMG), Belo Horizonte (MG), Brazil
} 


\section{Introduction}

Suicidal behavior is any deliberate action with potentially lifethreatening consequences, such as taking a drug overdose or deliberately crashing a car. It is a complex phenomenon with biological, environmental, developmental and learning contributory factors. ${ }^{1}$ It is well established that suicidal behavior is under genetic control and that this familial transmission is independent of the transmission of psychiatric disorders itself and linked to a serotonergic dysfunction. ${ }^{2}$ Suicide method has been used in studies of suicide attempters to select patients who are more likely to have low indexes of serotonergic neurotransmission, which in turn tend to correlate with higher levels of aggression. ${ }^{3}$ Therefore, patients who have attempted suicide using violent methods, such as jumping from a height, shooting or hanging, should constituted a peculiar group with a stronger genetic determinism, what justifies the distinction between violent and non-violent attempters when studying suicidal behavior.

In recent years, there has been a growing interest in the polarity of bipolar disorder (BD) (polarity at onset, as well as predominance of polarity during the course of this disease), since some studies have suggested that polarity could be a confident marker of course and/or prognosis in BD. ${ }^{4-9}$ Recently, a study carried out by Chaudhury et al., replicating previous results, ${ }^{4,9}$ showed that patients presenting depression as the first episode were at higher risk of suicide attempts even when adjusting for years with disease and total number of lifetime major depressive episodes. ${ }^{10}$ These studies are important, since they can provide a better understanding of BD clinical heterogeneity and particularly of suicidal behavior in BD.

In fact, studies on the association between BD and suicidal behavior have gained interest in recent years. The disorder probably exhibits the highest risk of suicidal behavior amongst all psychiatric disorders. ${ }^{11}$ Suicide rates in BD patients average approximately $1 \%$ annually, about 60 -fold the international population rate of $0.015 \%$, while nearly one third of patients acknowledge at least one suicide attempt. ${ }^{12}$ In contrast to suicides observed in other diagnosis groups, ${ }^{13,14}$ these attempts do not correlate with sociodemographic characteristics such as marital status, lack of employment, early loss or social isolation. ${ }^{15}$ Thus, we may speculate that the elevated suicide rates found in this group may be primarily explained by factors related to BD itself.

We performed this independent retrospective study in a wellcharacterized and large sample of bipolar patients in order to ascertain whether bipolar patients whose first episode was depressive had a history of more suicide attempts in general or violent suicide attempts. To our knowledge, there are no previous studies that specifically addressed the issue of the association between polarity of the first episode and violent suicide attempt.

\section{Methodology}

For the present study, consecutive bipolar patients ( $n=212$ ) admitted for treatment as outpatients $(n=71)$ or inpatients ( $n=141)$ to a psychiatric service specialized in BD treatment (IPSEMG) were enrolled. Patients were diagnosed according to the DSM-IV criteria based on a structured interview (MINI-PLUS). ${ }^{16}$ The subjects were interviewed in euthymia and grouped according to type of first episode: depression (FD) or manic/hypomanic (FM). Patients $(n=44)$ who had mixed first episodes or presented the disease with depression and mania within a one-year period were excluded from our analysis. Therefore, the statistical analyses were performed using 168 patients subgrouped as bipolar I, n = 49

Rev Bras Psiquiatr. 2009;31(2):114-8
(29.2\%); bipolar II, $\mathrm{n}=107$ (63.7\%) and bipolar NOS, $\mathrm{n}=12$ (7.1\%). The NOS subgroup was composed of patients who had mixed depression according to a definition validated by Akiskal and Benazzi (full depression episode plus at least three co-occurring intradepressive hypomanic symptoms: racing thoughts, irritability, decreased need for sleep, distractibility, psychomotor agitation, inflated self-esteem or more talkativeness). ${ }^{17}$

A psychiatrist assessed suicide lifetime history using a semistructured interview, and performed a review of medical records, as previously described. ${ }^{18,19}$ Furthermore, a supplementary interview with at least one close family member was performed in order to confirm patient information. Suicide attempt was defined as a conscious intent of the patient to end his/her life, even if ambivalent, through means that the patient believed could result in death. ${ }^{20}$ The suicide attempt methods were classified as non-violent (drug overdose) or violent (cuts beyond superficial scratch, jumping from a height, shooting, hanging), as previously defined. ${ }^{21}$

The diagnosis of psychosis was attributed to those patients who had complained about occurrence of hallucinations and/or delusions during at least one affective episode.

All procedures were approved by the local ethics committee and were in accordance with the Helsinki Declaration of 1975. All participants signed an informed consent form after receiving a full explanation of the study.

Since we found non-normal distribution for some variables, groups were compared according to polarity of the first episode using Mann-Whitney test for quantitative variables. Categorical variables were analyzed using chi-square tests. For the variables presenting statistically significant differences between groups (gender, type of $\mathrm{BD}$, and lifetime history of psychotic episodes) zero-inflated Poisson regression analyses were performed, considering the number of suicide attempts as a dependent variable. Finally, logistic regression analysis was used to test the relationship between the type of suicide attempt (violent $x$ non-violent) and those variables that had shown statistically significant differences between groups (polarity of the first mood episode, lifetime history of psychotic symptoms, type of bipolar affective disorder, gender, and type of BD).

\section{Results}

Patients grouped according to polarity of the first episode into the FD or the FM group were statistically different in: higher proportion of females in the FD group $\left(X^{2}=8.579 ; p=0.003\right)$, higher proportion of bipolar type II patients in the FD group $\left(X^{2}=19.726 ; p=0.0001\right)$, and higher proportion of lifetime history of psychotic episodes in the FM group $\left(X^{2}=4.769\right.$; $p=0.037)$. Other sociodemographic and clinical variables that did not reach statistical significance were: age, marital status, age at first mood episode, number of comorbidities, type of comorbidity, lifetime number of manic episodes and lifetime number of major depressive disorders (Table 1 ).

In terms of suicidal behavior, we found that the FD group had more frequent history of suicide attempts (51 vs. 37.9\%); however, this did not reach statistical significance $\left(X^{2}=2.77 ; p=0.10\right)$. Nevertheless, FD patients had more suicide attempts over time ( 1.48 vs. $0.92, z=2.03, p=0.042$ ). Analysis of suicide attempts by subtype, violent or non-violent, revealed that FM patients had a higher tendency to attempt suicide violently (21.2 vs. $14.7 \%$, $\mathrm{X}^{2}=7.028, \mathrm{p}=0.03$ ) compared to FD patients (Table 1 ). Considering only subjects with history of hospitalization ( $n=134$; $F M=59 ; F D=75$ ), we found the same pattern of results, but the differences between polarity groups are statistically more significant 
Table 1 - Relationship of first episode polarity to clinical and demographic variables in 168 patients with bipolar disorder

\begin{tabular}{|c|c|c|c|c|c|c|}
\hline \multirow[t]{2}{*}{ Clinical or demographic variables } & \multicolumn{2}{|c|}{$\begin{array}{l}\text { First manic/hypomanic } \\
\text { episode }(n=66)\end{array}$} & \multicolumn{2}{|c|}{$\begin{array}{l}\text { First depressive episode } \\
\qquad(n=102)\end{array}$} & \multirow{2}{*}{$\begin{array}{c}\mathrm{X}^{2} \text { or Mann- } \\
\text { Whitney, when } \\
\text { applicable }\end{array}$} & \multirow[t]{2}{*}{$\mathrm{p}$} \\
\hline & Mean or $n$ & SD or $(\%)$ & Mean or $n$ & SD or $(\%)$ & & \\
\hline Age (years) & 41.7 & \pm 13.8 & 42.5 & \pm 12.2 & -0.58 & 0.55 \\
\hline Gender (female) & 39 & $(56.1 \%)$ & 79 & $(77.5 \%)$ & 8.579 & 0.003 \\
\hline Married & 25 & $(37.9 \%)$ & 45 & $(44.1 \%)$ & 2.655 & 0.753 \\
\hline Age at the $1^{\text {st }}$ mood episode (years) & 23.9 & \pm 10.5 & 23.8 & \pm 10.4 & -1.002 & 0.316 \\
\hline Duration of illness (years) & 17.6515 & 12.59364 & 17.5545 & 12.72830 & 0.011 & .991 \\
\hline DSM-IV bipolar II subtype & 10 & $(15.2 \%)$ & 39 & $(38.2 \%)$ & 19.726 & 0.0001 \\
\hline Number of comorbidities & 1.9 & \pm 1.7 & 2.0 & \pm 1.5 & -0.704 & 0.48 \\
\hline Generalized anxiety disorders & 28 & $(42.4 \%)$ & 51 & $(50.0 \%)$ & 3.553 & 0.169 \\
\hline Panic disorders & 14 & $(21.2 \%)$ & 28 & $(27.5 \%)$ & 3.658 & 0.161 \\
\hline Cluster B personality disorder & 12 & $(18.2 \%)$ & 25 & $(24.5 \%)$ & 3.763 & 0.152 \\
\hline Smoking & 31 & $(47.0 \%)$ & 52 & $(51.0 \%)$ & 1.941 & 0.379 \\
\hline History of alcohol abuse/dependence & 17 & $(25.8 \%)$ & 33 & $(32.4 \%)$ & 1.638 & 0.441 \\
\hline History of drug abuse/dependence & 13 & $(19.7 \%)$ & 13 & $(12.7 \%)$ & 3.733 & 0.155 \\
\hline Lifetime number of major depressive episodes & 4.7 & \pm 5.6 & 6.5 & \pm 5.9 & -1.564 & 0.12 \\
\hline $\begin{array}{l}\text { Lifetime number of manic (or hypomanic) } \\
\text { episodes }\end{array}$ & 9.8 & \pm 8.4 & 10.0 & \pm 10.6 & -0.909 & 0.36 \\
\hline Total number of episodes & 15.0 & \pm 11.9 & 17.0 & \pm 15.1 & -0.329 & 0.74 \\
\hline Lifetime history of psychotic episodes & 18 & $(27.3 \%)$ & 14 & $(13.7 \%)$ & 4.769 & 0.037 \\
\hline Lifetime history of suicide attempt & 25 & $(37.9 \%)$ & 52 & $(51 \%)$ & 2.77 & 0.10 \\
\hline $\begin{array}{l}\text { Number of suicide attempts } \\
\text { History of violent suicide attempts }\end{array}$ & $\begin{array}{c}0.92 \\
14\end{array}$ & $\begin{array}{l} \pm 1.41 \\
(21.2 \%)\end{array}$ & $\begin{array}{c}1.48 \\
15\end{array}$ & $\begin{array}{l} \pm 2.07 \\
(14.7 \%)\end{array}$ & $\begin{array}{r}-2.03 \\
7.028\end{array}$ & $\begin{array}{l}0.04 \\
0.03\end{array}$ \\
\hline Attempts/duration of illness & 0.13 & 0.33 & 0.21 & 0.69 & -0.1165 & 0.24 \\
\hline
\end{tabular}

in this comparison: FD patients presented more suicide attempts over time ( 1.8 vs. $1.0, z=2.325, p=0.02)$ and the FM group had more frequency of violent suicide attempts (58.3 vs. $31.1 \%$, $X^{2}=4.810, p=0.027$ ).

We performed a zero-inflated Poisson regression analysis of the number of suicide attempts in order to examine its relationship with first episode polarity. Our primary model included the independent variables that had reached statistical significance in Table 1, namely, gender, bipolar type II diagnosis, polarity of the first episode and history of psychotic episodes. We found that the best model fitted with bipolar II subtype $(B=0.373 ;$ S.E. $=0.157 ; z=2.37$; $\mathrm{p}=0.018 ; 95 \% \mathrm{Cl}=0.065$ to 0.681$)$ and lifetime history of psychotic episodes $(B=0.552 ;$ S.E. $=0.243 ; z=2.26$; $\mathrm{p}=0.023 ; 95 \% \mathrm{Cl}=0.705$ to 1.03$)$. The other variables described above (gender and polarity of the first episode) did not reach statistical significance.

In addition, we performed multiple logistic regression analysis of patients with a history of violent suicide attempt in order to investigate its relationship with first episode polarity (manic) correcting for possible confounding factors (gender, bipolar II diagnosis and lifetime history of psychotic symptoms). This analysis confirmed that the FM subgroup had a higher association with history of violent suicide attempt (OR $=4.083, p=0.015,95 \%$ $\mathrm{Cl}=1.32$ to 12.64 ).

\section{Discussion}

Our results are only partially in accordance with those reported by Chaudhury et al. ${ }^{10}$ These authors found a significant association between the FD group and a more frequent lifetime history of suicide attempt and number of suicide attempts. In our sample, the frequency of suicide attempters in the FD group was not statistically different from the frequency of suicide attempters in the FM group (51 vs. $37.9 \%$, respectively, $p=0.08$ ). Nevertheless, as found in the Chaudhury et al., 2007 study, suicide attempters belonging to the FD group made more suicide attempts than suicide attempters belonging to the FM group. ${ }^{10}$
In our sample, FD and FM were different in terms of the percentage of bipolar type II, which was higher in the FD group (38.2 vs. $15.2 \%$ ), as well as proportion of female gender (77.5 vs. $56.1 \%$ ), lifetime history of psychotic symptoms and finally, number of lifetime suicide attempts (1.48 vs. 0.92). After performing a zero-inflated Poisson regression analysis in order to verify the independence of these variables regarding suicidal behavior, we found that the only characteristics associated with number of suicide attempts were diagnosis of bipolar II and lifetime history of psychotic symptoms. In other words, with regard to the number of suicide attempts, the strongest association was with bipolar II diagnosis or history of psychotic symptoms and not first polarity depressive episode. This gives two distinct groups at higher risk of suicide: bipolar II patients and patients with lifetime history of psychotic symptoms. Several previous studies have shown that bipolar II patients have a higher risk of suicide attempt than both bipolar I patients ${ }^{22}$ or unipolar depressed patients. ${ }^{23}$ This finding could possibly be explained by the higher propensity of bipolar II patients for comorbidity with personality disorders, substance abuse, and anxiety compared with other mood disorders. ${ }^{11}$ Additionally, bipolar II patients spend longer in depression, have less interepisode intervals and a higher number of episodes in general. ${ }^{24}$ The association between number of depressive episodes and suicidal behavior is well known. Several studies and clinical observations from bipolar and unipolar samples have shown that depression is strongly correlated with suicide. ${ }^{11}$ A study found that rates of suicide attempt varied markedly between different phases of $\mathrm{BD}$, being more frequent during episodes accompanied with depressive symptoms (depression, mixed and depressive mixed) and being absent from the hypomanic/manic phase. ${ }^{25}$

A 10-year prospective study of bipolar patients found that those who have depression polarity predominance have higher prevalence of bipolar II disorder, higher probability of depressive onset and higher rates of suicidal behavior (lifetime history of suicide attempt, suicide ideation and higher number of suicide attempts over time). ${ }^{26}$ Finally, a prospective study over an 18-month period found that previous suicide attempt, hopelessness, depressive phase at index 
episode and younger age at intake were independent risk factors for suicide attempts. ${ }^{27}$ In contrast to our findings, the authors did not find association with bipolar II. This lack of accordance maybe reflects the heterogeneity of bipolar II samples.

Our second positive association of lifetime history of psychotic symptoms and number of suicide attempts is harder to explain mainly because history of psychotic symptoms could be encompassed in a heterogenic group. Psychotic symptoms could be secondary to episodes, being a marker of severity of mood episodes, or mood episodes could act as a trigger for the manifestation of schizophrenic diathesis. Unfortunately, the methodology used in our study does not allow distinguishing these groups. Some studies using similar methodology to characterize psychosis have shown that psychotic symptoms in BD are associated with poor outcome, ${ }^{28,29}$ but the relationship between psychosis and suicide in mood disorders remains unclear. Previous studies have only shown risk of suicidality (suicide attempt and suicide ideation) to be associated with psychosis in pediatric patients ${ }^{30}$ and adolescents with $\mathrm{BD},{ }^{31}$ but not in adult patients. ${ }^{32}$ However, one larger follow-up study of 44 years found that psychotic symptoms in BD were associated with complete suicide in adults. ${ }^{33}$

We performed an additional analysis, characterizing the type of suicide attempt as violent or non-violent, and showing that FM patients had a more frequent history of violent suicide attempt compared to FD patients. A multiple logistic regression analysis corrected for possible confounding factors confirmed this result and showed that the FM subgroup had a higher association with history of violent suicide attempt.

These results support the evidence that non-violent suicide attempters and violent suicide attempters tend to belong to different phenotypic groups. In fact, several studies with genetic and biological perspectives have shown that violent attempters represent a subgroup of suicide attempters with a more consistent phenotype. ${ }^{34,35}$ Furthermore, suicidal behavior is a complex phenomenon with biological, environmental, developmental and learning contributory factors. In view of this multi-determinism, we can speculate that some factors, for instance, polarity in BD, could play a major role in some categories of suicidal behavior (i.e. violent, non-violent, multiple suicide attempts etc.), but not in all.

Our study has several limitations. The most important one concerning the retrospective design of this study, for it is well known that many patients have difficulty recalling hypomanic episodes. Additionally, the use of retrospective analysis makes recall of severity and duration of manic and depressive episodes almost impossible, where these represent important variables with possible association with suicidal behavior. A prospective study would enable other issues to be explored, such as whether FM patients have a higher prevalence during episodes of higher scores on impulsivity, hostility or hopelessness. We also deem it necessary to consider the influence of treatment because many patients, before being diagnosed as bipolar II, could have been misdiagnosed as unipolar depression, thereby delaying appropriate treatment. Moreover, several studies have shown that lithium would be more efficacious than valproic acid or carbamazepine in the prevention of suicidal behavior ${ }^{36}$ and another study has shown that BD patients have low adherence (20-60\%) to the treatment. ${ }^{37}$ We believe that only prospective studies including periodical serum analyses of medication are able to definitively clarify the influence of this variable.

Our sample is overrepresented by more severe patients because these were drawn from secondary and tertiary services. Thus, it is difficult to extrapolate these results to the entire spectrum of BD patients. Should these data be confirmed by prospective studies, they could help predict an adverse course using relatively reliable data and the polarity of the first episode.

\section{Acknowledgments}

We acknowledge the financial support from Fundação de Amparo à Pesquisa de Minas Gerais (FAPEMIG) and Conselho Nacional de Desenvolvimento Científico e Tecnológico (CNPq). Register CONEPE: 7430, process: 25000.021164/2003-52.

Disclosures

\begin{tabular}{|c|c|c|c|c|c|c|c|}
\hline $\begin{array}{l}\text { Writting group } \\
\text { member }\end{array}$ & Employment & $\begin{array}{c}\text { Research } \\
\text { grant }^{1}\end{array}$ & $\begin{array}{l}\text { Other research grant } \\
\text { or medical } \\
\text { continuous education }^{2}\end{array}$ & $\begin{array}{l}\text { Speaker's } \\
\text { honoraria }\end{array}$ & $\begin{array}{l}\text { Ownership } \\
\text { interest }\end{array}$ & $\begin{array}{l}\text { Consultant/ } \\
\text { Advisory board }\end{array}$ & Other $^{3}$ \\
\hline $\begin{array}{l}\text { Fernando Silva } \\
\text { Neves }\end{array}$ & UFMG & - & Astra-Zeneca* & - & - & - & - \\
\hline $\begin{array}{l}\text { Leandro Mallo- } \\
\text { Diniz }\end{array}$ & UFMG & - & - & - & - & - & - \\
\hline $\begin{array}{l}\text { Paulo Marcos } \\
\text { Brasil }\end{array}$ & UFMG & - & - & - & - & - & - \\
\hline $\begin{array}{l}\text { Izabela Guimarães } \\
\text { Barbosa }\end{array}$ & UFMG & - & IBN-Net* & - & - & - & - \\
\hline Humberto Corrêa & UFMG & $\begin{array}{l}\text { FAPEMIG } \\
\text { CNPq }\end{array}$ & - & Lilly* & - & - & - \\
\hline \multicolumn{8}{|c|}{$\begin{array}{l}\text { *Modest } \\
\text { ** Significant } \\
\text { *** Significant. Amounts given to the author's institution or to a colleague for research in which the author has participation, not directly to the author. } \\
\text { Note: UFMG = Universidade Federal de Minas Gerais; FAPEMIG = Fundação de Amparo à Pesquisa do Estado de Minas Gerais; CNPq = Conselho Nacional de } \\
\text { Desenvolvimento Cientifico e Tecnológico; IBN-NET = Rede Instituto Brasileiro de Neurociências. } \\
\text { For more information, see Instructions for authors. }\end{array}$} \\
\hline
\end{tabular}




\section{References}

1. National Library Medicine: MedlinePlus. Suicide and behavior. [cited 2009 Feb 22]. Available from: http://www.nlm.nih.gov/medlineplus/ ency/article/001554.htm

2. Bondy B, Buettner A, Zill P. Genetics of suicide. Mol Psychiatry. 2006;11(4):336-51.

3. Brown GL, Ebert MH, Goyer PF, Jimerson DC, Klein WJ, Bunney WE, Goodwin FK. Aggression, suicide, and serotonin: relationships to CSF amine metabolites. Am J Psychiatry. 1982;139(6):741-6.

4. Perlis RH, Delbello MP, Miyahara S, Wisniewski SR, Sachs GS, Nierenberg AA. Revisiting depressive-prone bipolar disorder: polarity of initial mood episode and disease course among bipolar I systematic treatment enhancement program for bipolar disorder participants. Biol Psychiatry. 2005;58(7):549-53.

5. Perris C, d'Elia G. A study of bipolar (manic-depressive) and unipolar recurrent depressive psychoses. X. Mortality, suicide and life-cycles. Acta Psychiatr Scand Suppl. 1966;194:172-89.

6. Perugi G, Micheli C, Akiskal HS, Madaro D, Socci C, Quilici C, Musetti L. Polarity of the first episode, clinical characteristics, and course of manic depressive illness: a systematic retrospective investigation of 320 bipolar I patients. Compr Psychiatry. 2000;41(1):13-8.

7. Roy-Byrne P, Post RM, Uhde TW, Porcu T, Davis D. The longitudinal course of recurrent affective illness: life chart data from research patients at the NIMH. Acta Psychiatr Scand Suppl. 1985; 317:1-34.

8. Calabrese JR, Vieta E, El-Mallakh R, Findling RL, Youngstrom EA, Elhaj O, Gajwani P, Pies R. Mood state at study entry as predictor of the polarity of relapse in bipolar disorder. Biol Psychiatry. 2004;56(12):957-63.

9. Quitkin FM, Rabkin JG, Prien RF. Bipolar disorder: are there manicprone and depressive-prone forms? J Clin Psychopharmacol. 1986;6(3):167-72.

10. Chaudhury SR, Grunebaum MF, Galfalvy HC, Burke AK, Sher L, Parsey RV, Everett B, Mann JJ, Oquendo MA. Does first episode polarity predict risk for suicide attempt in bipolar disorder? J Affect Disord. 2007;104(1-3):245-50.

11. Goodwin FK, Jamison KR. Manic-depressive illness: bipolar disorders and recurrent depression. 2nd ed. New York: Oxford University Press; 2007.

12. Muller-Oerlinghausen B, Berghofer A, Bauer M. Bipolar disorder. Lancet. 2002;359(9302):241-7.

13. Osborn D, Levy G, Nazareth I, King M. Suicide and severe mental illnesses. Cohort study within the UK general practice research database. Schizophr Res. 2008; 99(1-3):134-8.

14. Gonda X, Fountoulakis KN, Kaprinis G, Rihmer Z. Prediction and prevention of suicide in patients with unipolar depression and anxiety. Ann Gen Psychiatry. 2007;6:23.

15. Hawton K, Sutton L, Haw C, Sinclair J, Harriss L. Suicide and attempted suicide in bipolar disorder: a systematic review of risk factors. J Clin Psychiatry. 2005;66(6):693-704.

16. Amorim P. Mini International Neuropsychiatric Interview (MINI): validation of a short structured diagnostic psychiatric interview. Rev Bras Psiquiatr. 2000;22(3):106-15.

17. Akiskal HS, Benazzi F. Delineating depressive mixed states: their therapeutic significance. Clin Approaches Bipolar Disord. 2003;2:41-7.

18. Corrêa H, Duval F, Mokrani MC. Prolactin response to D-fenfluramine and suicidal behavior in depressed patients. Psychiatry Res. 2000;93(3):189-99.

19. Corrêa H, Duval F, Mokrani MC. Serotoninergic function and suicidal behavior in schizophrenia. Schizophr Res. 2002;56(1-2):75-85.

20. Asberg M, Traskman L, Thohen P. 5-HIAA in the cerebrospinal fluid. A biochemical suicide predictor? Arch Gen Psychiatry. 1976;33(10):1193-7.

21. Coccaro EF, Sielver LJ, Klar HM. Serotoninergic studies in patients with affective and personality disorders correlates with suicidal and impulsive aggressive behavior. Arch Gen Psychiatry. 1989;46(7):587-99.

22. Rihmer Z, Kiss P. Bipolar disorders and suicide behavior. Bipolar Disord. 2002;4(1):21-5.

23. Bulik CM, Carpenter LL, Kupfer DJ, Frank E. Features associated with suicide attempts in recurrent major depression. J Affect Disord. 1990;18(1):29-37.
24. Judd LL, Schettler PJ, Akiskal HS, Maser J, Coryell W, Solomon $\mathrm{D}$, Endicott J, Keller M. Long-term symptomatic status of bipolar I vs. bipolar II disorders. Int J Neuropsychopharmacol. 2003;6(2): 127-37.

25. Valtonen HM, Suominen K, Mantere O, Leppämäki S, Arvilommi P, Isometsä E. Suicidal behaviour during different phases of bipolar disorder. J Affect Disord. 2007;97(1-3):101-7.

26. Colom F, Vieta E, Daban C, Pacchiarotti I, Sánchez-Moreno J. Clinical and therapeutic implications of predominant polarity in bipolar disorder. J Affect Disord. 2006;93(1-3):13-7.

27. Valtonen HM, Suominen K, Mantere O, Leppämäki S, Arvilommi P, Isometsä ET. Prospective study of risk factors for attempted suicide among patients with bipolar disorder. Bipolar Disord. 2006;8(5 Pt 2):576-85.

28. Strakowski SM, Williams JR, Sax KW, Fleck DE, DelBello MP, Bourne $\mathrm{ML}$. Is impaired outcome following a first manic episode due to moodincongruent psychosis? J Affect Disord. 2000;61(1-2):87-94.

29. Goldberg JF, Harrow M. Consistency of remission and outcome in bipolar and unipolar mood disorders: a 10-year prospective followup. J Affect Disord. 2004;81(2):123-31.

30. Caetano SC, Olvera RL, Hunter K, Hatch JP, Najt P, Bowden C, Pliszka S, Soares JC. Association of psychosis with suicidality in pediatric bipolar I, II and bipolar NOS patients. J Affect Disord. 2006;91(1):33-7.

31. Papolos D, Hennen J, Cockerham MS. Factors associated with parent-reported suicide threats by children and adolescents with community-diagnosed bipolar disorder. J Affect Disord. 2005;86(23):267-75.

32. Black DW, Winokur G, Nasrallah A. Effect of psychosis on suicide risk in 1,593 patients with unipolar and bipolar affective disorders. Am J Psychiatry. 1988;145(7):849-52.

33. Angst J, Angst F, Gerber-Werder R. Gamma A. Suicide in 406 mooddisorder patients with and without long-term medication: a 40 to 44 years' follow-up. Arch Suicide Res. 2005;9(3):279-300.

34. Spreux-Varoquaux O, Alvarez JC, Berlin I, Batista G, Despierre $P G$, GiltonCremniter D. Differential abnormalities in plasma 5-HIAA and platelet serotonin concentrations in violent suicide attempters: relationships with impulsivity and depression. Life Sci. 2001;69(6):647-57.

35. Neves FS, Silveira G, Romano-Silva MA, Malloy-Diniz L, Ferreira AA, De Marco L, Correa H. Is the 5-HTTLPR polymorphism associated with bipolar disorder or with suicidal behavior of bipolar disorder patients? Am J Med Genet B Neuropsychiatr Genet. 2008;147B(1):114-6.

36. Cipriani A, Pretty H, Hawton K, Geddes JR. Lithium in the prevention of suicidal behavior and all-cause mortality in patients with mood disorders: a systematic review of randomized trials. Am J Psychiatry. 2005;162(10):1805-19.

37. Colom F, Vieta E, Tacchi MJ, Sanchez-Moreno J, Scott J. Identifying and improving non-adherence in bipolar disorders. Bipolar Disord. 2005;7 Suppl 5:24-31. 